\title{
The prevalence of multiple sclerosis in the Outer Hebrides compared with north-east Scotland and the Orkney and Shetland Islands
}

\author{
GEOFFREY DEAN \\ From the Medico-Social Research Board, Dublin \\ JOHN GOODALL \\ From Lewis Hospital, Stornoway
}

\author{
ALLAN DOWNIE \\ From Aberdeen Royal Infirmary, Aberdeen
}

SUMMARY Multiple sclerosis has been reported to have a high prevalence in the Orkney and Shetland Islands and in Caithness in comparison with the highlands of Scotland and the Outer Hebrides-the Western Isles. For this reason a survey was undertaken in the Outer Hebrides and 25 probable and 30 probable and possible patients with multiple sclerosis were found. This is an increase from eight and 11 respectively found in 1954 . The present prevalence rate of 97.3 per 100000 for probable and possible multiple sclerosis is not significantly different from that found in a recent study in the Grampian region in north-east Scotland. Repeated studies in small populations generally show increasing prevalence of multiple sclerosis because some patients are missed in the earlier studies, and over a long period of time there may also be some increase in survival time. This increase has been found in the Orkney and Shetland Islands, in north-east Scotland, and also in the Outer Hebrides.

The Orkney and Shetland Islands have been reported to have a high prevalence of multiple sclerosis (MS). In the latest of four surveys the prevalence of MS in these islands had risen from 111 (1954) to 309 per 100000 in the Orkney Islands and from 134 to 184 per 100000 in the Shetland Islands when probable and possible MS were taken together, and from 82 (1954) to 258 in the Orkneys and 118 to 152 in the Shetlands per 100000 for probable MS alone. ${ }^{1-4}$ (Table 1).
Two recent studies of MS prevalence in 28 areas in north-east Scotland showed a prevalence of 105 per 100000 for probable MS and 127 for probable and possible MS in the first survey, and 117 probable MS and 144 probable and possible MS in the second survey. ${ }^{.0}$ (Table 2 ).

In 1956 Sutherland reported that the prevalence of MS appeared to be more common in the Orkney and Shetland Islands than in the highlands of Scotland and in the Outer Hebrides, and postulated that there

Table 1 Probable and possible MS: First and subsequent studies in the Orkneys, Shetlands and Outer Hebrides

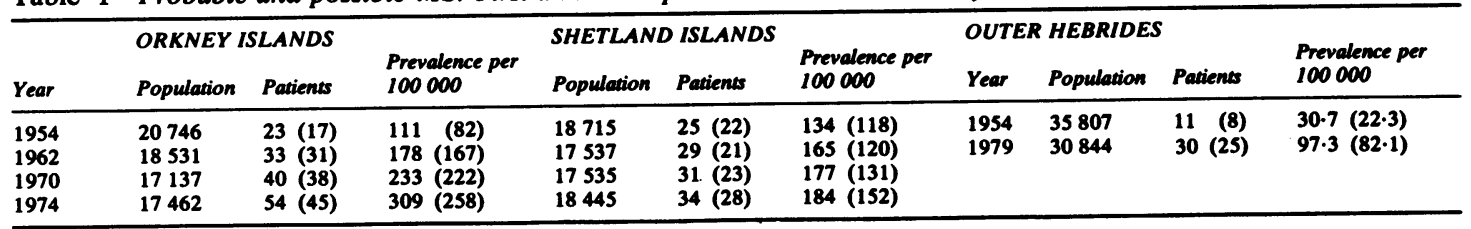

Probable MS patients and rates for probable MS per 100000 in brackets. 
Table 2 Prevalence of probable and possible MS by area, north-east Scotland *

\begin{tabular}{|c|c|c|c|c|c|}
\hline \multirow[b]{2}{*}{$\begin{array}{l}\text { Area } \\
\text { no. }\end{array}$} & \multirow[b]{2}{*}{ Population } & \multicolumn{2}{|c|}{ FIRST STUDY (I DECEMBER 1970)" } & \multicolumn{2}{|c|}{ SECOND STUDY (I DECEMBER 1973) } \\
\hline & & $\begin{array}{l}\text { No. of } \\
\text { patients } \\
\text { with MS }\end{array}$ & $\begin{array}{l}\text { Prevalence per } \\
100000 \\
\text { population }\end{array}$ & $\begin{array}{l}\text { No. of } \\
\text { patients } \\
\text { with MS }\end{array}$ & $\begin{array}{l}\text { Prevalence per } \\
100000 \\
\text { population }\end{array}$ \\
\hline 1 & 9623 & 13 & $135 \cdot 1$ & 13 & $135 \cdot 1$ \\
\hline 2 & 9923 & 8 & 80.6 & 10 & $100 \cdot 8$ \\
\hline 3 & 18121 & 11 & 60.7 & 14 & $77 \cdot 3$ \\
\hline 4 & 11768 & 23 & 195.4 & 22 & 186.9 \\
\hline 5 & 17392 & 20 & 115.0 & 21 & 120.7 \\
\hline 6 & 21439 & 15 & 70.0 & 18 & 84.0 \\
\hline 7 & 15748 & 29 & $184 \cdot 2$ & 33 & 209.6 \\
\hline 8 & 14507 & 27 & 186.1 & 31 & 213.7 \\
\hline 9 & 11160 & 17 & 152.3 & 22 & $197 \cdot 1$ \\
\hline 10 & 16248 & 27 & 166.2 & 30 & 184.6 \\
\hline 11 & 19875 & 22 & 110.7 & 27 & 135.8 \\
\hline 12 & 15349 & 18 & $117 \cdot 3$ & 16 & $104 \cdot 2$ \\
\hline 13 & 14160 & 13 & 91.8 & 15 & 105.9 \\
\hline 14 & 10606 & 19 & 179.1 & 23 & 216.9 \\
\hline is & 20415 & 16 & 78.4 & 19 & 93.1 \\
\hline 16 & 10768 & 27 & 250.7 & 26 & $241 \cdot 5$ \\
\hline 17 & 17027 & 20 & $117 \cdot 5$ & 27 & 158.6 \\
\hline 18 & 14635 & 18 & 123.0 & 23 & $157 \cdot 2$ \\
\hline 19 & 14220 & 24 & $168 \cdot 8$ & 28 & 196.9 \\
\hline 20 & 36130 & 50 & 138.4 & 55 & 152.2 \\
\hline 21 & 15242 & 22 & $144 \cdot 3$ & 23 & 150.9 \\
\hline 22 & 16537 & 21 & 127.0 & 16 & 96.8 \\
\hline 23 & 11724 & 19 & 162.1 & 20 & 170.6 \\
\hline 24 & 11913 & 18 & $151 \cdot 1$ & 21 & $176 \cdot 3$ \\
\hline 25 & 14146 & 9 & 63.6 & 20 & $141 \cdot 4$ \\
\hline 26 & 20050 & 25 & 124.7 & 30 & 149.6 \\
\hline 27 & 16343 & 19 & $116 \cdot 3$ & 20 & 122.4 \\
\hline 28 & 15107 & 7 & $46 \cdot 3$ & 11 & $72 \cdot 8$ \\
\hline TOTAL & 440176 & 557 & 126.5 & 634 & $144 \cdot 0$ \\
\hline
\end{tabular}

might be a disadvantageous genetic factor in the north-eastern county of Caithness and in the Orkney and Shetland Islands, where the people are largely of Scandinavian origin, in comparison with mainland Ross and Cromarty, Inverness, and the Outer Hebrides, where the people are often still Gaelic-speaking and more often of Celtic origin. ${ }^{1}$ (Table 1). Because of the recently reported high prevalence of MS in north-east Scotland in the Grampian region centred on Aberdeen, as well as in the Orkney and Shetland Islands, we undertook to ascertain the prevalence of MS in the Outer Hebrides-the Western Isles.

\section{Method}

A search was made for all possible and probable patients with MS through the records at the General Hospital, Stornoway, and the neurological records at the hospitals in Glasgow and Aberdeen. All the doctors on the islands co-operated in the study. Of the 30844 residents on the islands (1979), 24000 live on the island of Lewis and Harris. There are seven general practitioners in the only town of the Western Isles, Stornoway, with six doctors in practice in the rest of Lewis and Harris, one in North Uist, two in Benbecula and also in South Uist, and one on the island of Barra. The visiting ophthalmologist from
Inverness who holds clinics throughout the Western Isles also co-operated in the study, which lasted four years.

\section{Results}

All patients who were suspected of having MS were examined personally by the team, either in hospital at Stornoway or in their homes, with the exception of one well-documented patient who returned to the mainland. The majority of patients had extensive hospital records and some were admitted to hospital in Aberdeen for further investigation during the course of this study.

On prevalence day, 1 July 1979, there were 25 patients diagnosed as having probable MS, 11 men and 14 women. There were five patients with possible MS and four patients with a history of retrobulbar neuritis only. When the 30 probable and possible MS patients were taken together, the calculated MS prevalence rate was 97.3 per $100000(104 \cdot 3$ per 100000 when age-standardised to the population distribution of Scotland). The prevalence rate for probable MS was 82.1 per 100000 (87.6 per 100000 when age-standardised to the population of Scotland). There is high emigration from the Outer Hebrides of the age group $20-44$ with high risk of MS, who constitute only $25 \%$ of the population 
compared with $31.6 \%$ for Scotland, $29.9 \%$ for the Orkneys, and 31.9\% for the Shetlands (1975).

Of the 25 patients with probable MS, five lived in Stornoway, three in the remainder of Lewis, seven in Harris in four families (in one family there were twin brothers affected and a sister, and in another family a brother and a sister), eight in North Uist in seven families (in one family a brother and a sister were affected), and two in Benbecula. No patients with probable MS were found in South Uist or in Barra. The mother of one of the patients also had MS but she was not living on the islands (Table 3).

Weakness in one or more limbs was the first symptom in nine of the 25 patients with probable MS, retrobulbar neuritis in seven, ataxia or paraesthesia in four each, and incontinence of urine in one. Twenty-three of the 25 patients had had remissions.

The mean age at onset for the MS patients was 35.8 years ( $37 \cdot 8$ for men, $34 \cdot 1$ for women) and the mean age on prevalence day 1979 was $46 \cdot 3$ years ( 49.8 for men and 43.5 for women).

HISTOCOMPATIBILITY LEUCOCYTE ANTIGENS The association between MS and certain histocompatibility leucocyte antigens (HLA) is now accepted and there is also evidence that they frequently share a common B-lymphocyte antigen. ${ }^{7}$ The HLA groups, A3, B7, DW2, are more common than expected in patients with MS. Blood was obtained from 18 of the 25 MS patients in the Outer Hebrides and tested by the North-east of Scotland Blood Transfusion Service for ABO blood group, rhesus factor and for A and B HLA factors. Six of the 18 patients had the HLA haplotype A3, B7. They included twin brothers and their sister, three siblings in one family with MS. Two other siblings with MS, a brother and sister, had HLA haplotype A1, AW32, B40 and A1, A W32, B8, B40 respectively. Another brother and sister with MS had the haplotype $A 1$, $A 2, B 8, B 12$ and $A 1, A 11, B 7$ and $B 8$ respectively. A further patient also had HLA B7, making seven with HLA B7 in five families and there were, in all, seven with HLA A3.

Table 3 Multiple Sclerosis in the Outer Hebrides (The Western Isles) 1 July 1979

\begin{tabular}{lccccc}
\hline & Population & Probable MS & Possible MS & $\begin{array}{l}\text { Retrobulbar } \\
\text { neuritis }\end{array}$ \\
\hline Stornoway & 12878 & 5 & $(5)$ & - & 1 \\
Rest of Lewis & 8177 & 3 & $(3)$ & 2 & 3 \\
Harris & 2655 & 7 & $(4)$ & - & - \\
$\begin{array}{l}\text { North Uist } \\
\text { Benbecula }\end{array}$ & 1618 & 8 & $(7)$ & 1 & - \\
South Uist & 4051 & 2 & $(2)$ & 1 & - \\
Barra & 1464 & - & - & - & - \\
TOTAL & 30844 & $25(21)$ & 5 & 4 \\
\hline
\end{tabular}

The number in brackets is the number of families affected.
In 1972 Dick et al carried out a study of HLA and other polymorphic systems among a population of 130 persons living in Stornoway and in other villages in Lewis. ${ }^{8}$ There was no significant difference in the HLA antigen frequencies of the MS patients and the controls from Stornoway and Glasgow. However, the number of MS patients was very small.

A recent study of HLA blood groups from a random population of Barra Island in the extreme south of the Outer Hebrides found a different HLA distribution from that found in Lewis, with a higher frequency of B7. ${ }^{\circ}$ Nevertheless, all the probable MS patients were in the Protestant northern parts of the Outer Hebrides as far south as Benbecula and no patient with probable MS has so far been found in the Catholic islands of South Uist and Barra. The two MS patients in Benbecula were not born in the Outer Hebrides.

\section{Discussion}

Other studies of MS prevalence have shown that the estimated prevalence is higher with each subsequent study. This has occurred in the Outer Hebrides, an increase of probable MS from eight to 25 , that is, from 22.3 to 82.1 per 100000 . It has also occurred in the Orkneys and Shetlands and in north-east Scotland (Tables 1 and 2). Inevitably, in the early studies some MS patients were overlooked and perhaps the patients are surviving a longer time and there may be a shorter period between onset and diagnosis. The prevalence rate of $82 \cdot 1$ per 100000 population for probable MS and $\mathbf{9 7 \cdot 3}$ for probable and possible MS (104.3 when age-standardised to the population of Scotland) found in this second prevalence study in the Outer Hebrides can be compared with 105 per 100000 for probable MS and 117 per 100000 for probable and possible MS found in the study in north-east Scotland based on prevalence day, 1 December $1970 .^{5}$ The number of MS patients now found in the Outer Hebrides (25 probable, 30 probable and possible) is not significantly different from the number expected based on the first study in north-east Scotland, when it would be 32.5 and 39.0 respectively. ${ }^{5}$ In a preliminary survey in the neighbouring island of Skye there were seven patients with probable MS in a population of just over 7000 people, confirming that the disease is common in the islands of the west of Scotland. Mortality rates for MS are higher in Scotland than in England but they are not significantly different between the counties of Scotland.

\section{Conclusion}

It is very difficult to ascertain a close approximation for MS prevalence, and repeated studies show higher 
prevalence rates because generally a number of patients had been missed in the earlier studies. A heightened awareness of MS among the doctors in a small community can also lead to a shorter interval between onset and diagnosis; this interval is usually about seven years. A higher degree of accuracy can be obtained by studying small populations in depth, but with small populations chance can also play an important role in prevalence.

In this study the prevalence of probable MS in the Outer Hebrides was 82.1 per 100000 and of probable and possible MS 97.3 per 100000 . The prevalence in the Outer Hebrides was not significantly different from that found in the first study in the Grampian region of north-east Scotland and was greater than that found in seven of the 28 subgroups of populations in the first north-east Scotland study and five of the same subgroups in the second study. ${ }^{3}$. The prevalence in the Outer Hebrides was similar to that found in the neighbouring island of Skye and within the range of prevalence expected for a population of similar size in Scotland. The prevalence of MS in the latest study in the Orkneys, and to a lesser extent in the Shetlands, was high, but other areas of similar population size in north-east Scotland also have a high prevalence.

We thank the doctors of the Outer Hebrides, all of whom collaborated with us in this study, and also the patients who agreed to be examined.
This study was supported by a grant from the Multiple Sclerosis Society of Great Britain and Northern Ireland (Scottish Branch).

Reprints from Dr. Geoffrey Dean, Director, the Medico-Social Research Board, 73 Lower Baggot Street, Dublin 2.

\section{References}

${ }^{1}$ Sutherland JM. Observations on the prevalence of multiple sclerosis in Northern Scotland. Brain 1956; 79: 635-53.

${ }^{2}$ Fog M, Hyllested L. Prevalence of disseminated sclerosis in the Faroes, the Orkneys and Shetlands. Acta Neurol Scand 1966; 42, suppl 19: 9.

'Poskanzer DC, Brody JA, Plank C. Unpublished data.

- Poskanzer DC, Walker AM, Yonkondy J, Sheridan JL. Studies in the epidemiology of multiple sclerosis in the Orkney and Shetland Islands. Neurology 1976; 26, part 2: 14-7.

shepherd DI, Downie AW. Prevalence of multiple sclerosis in north-east Scotland. $\mathrm{Br}$ Med J 1978; i: 314-6.

- Shepherd DI, Downie AW. A further prevalence study of multiple sclerosis in north-east Scotland. J Neurol Neurosurg Psychiatry 1980; 43(4): 310-5.

'Anonymous. Histocompatibility antigens and multiple sclerosis. Lancet 1976; it: 1286.

- Dick HM, Crichton WB, Ferguson-Smith MA, Izatt MM. Study of the HLA and other polymorphic systems in a Scottish population. Histocompatibility Testing. Copenhagen: Munksgaard, 1972.

- Dick HM, Izatt MM. HLA antigens and IgG allotypes on the Island of Barra (Outer Hebrides). Ann Hum Biol 1978; 5(5): 441-51. 